\title{
Transient Intraluminal Diverticulum of the Esophagus: A Significant Flow Artifact
}

\author{
Farooq P. Agha \\ Department of Radiology, University of Michigan Medical Center, Ann Arbor, Michigan, USA
}

\begin{abstract}
Esophagography in 12 patients showed a characteristic oval- to oblong-shaped barium collection surrounded by a thin radiolucent margin. The collection closely resembled an intraluminal diverticulum. Twelve patients demonstrated these findings, 6 on single-contrast and 6 on double-contrast examinations. These findings were not reproducible on repeat barium swallows, and endoscopy failed to demonstrate an intraluminal diverticulum. Nine of the patients underwent esophagectomy and esophageal substitution. Pathologic examination of the gross specimen did not reveal evidence of intraluminal diverticula. The association of this radiologic appearance in patients with moderately severe motility disorder of the esophagus is emphasized.
\end{abstract}

Key words: Esophagus, transient intraluminal diverticulum - Barium, flow artifact.

Esophagography in 12 patients showed a barium collection similar to intraluminal diverticulum of the duodenum. This appearance was transient and seen on only 1 or 2 radiographs. Moderately severe motility disorder of the esophagus was present in 8 of the 12 patients. Although this finding was not reproducible on repeat barium swallow, endoscopy in all cases and gross pathologic examination of the esophagus in 9 patients failed to show the presence of intraluminal diverticulum. However its recognition is important and signifies a possible underlying motility disorder of the esophagus.

Address reprint requests to: Farooq P. Agha, M.D., Department of Radiology, Box 13, University Hospital, Ann Arbor, MI 48109 , USA

\section{Methods and Material}

One thousand unselected contrast esophagograms performed at the University of Michigan Hospital, Ann Arbor, from January 1981 through June 1983 were reviewed. Twelve cases demonstrated an intraluminal esophageal diverticulum-like structure on barium swallows. The medical records and pertinent radiographic studies were reviewed. This group consisted of 5 men and 7 women ranging in age from 21 to 76 years. There were 4 patients with diffuse esophageal spasm, 2 with carcinoma of mid thoracic esophagus, 2 with caustic induced strictures, and 1 patient each with achalasia, peptic stricture, and scleroderma associated with severe gastroesophageal reflux. The clinical data - type of contrast esophagogram (single- vs. doublecontrast); endoscopic findings in all 12 patients; results of esophageal function studies including manometry, 24-hour $\mathrm{pH}$ monitoring, and acid clearance tests in 7 patients; and pathologic examination of 9 esophagi from patients who received substitutions using colon interposition or stomach - are detailed in Table 1. For single-contrast examination low-density barium mixture ( $40 \%$ weight by weight) was used. For double-contrast studies, high-density barium mixture ( $85 \%$ weight by weight) was utilized in this study.

\section{Results}

A transient intraluminal esophageal diverticulumlike structure was seen in 6 single-contrast and 6 double-contrast examinations (Figs. 1-3). Eight patients had moderately severe motility abnormalities of the esophagus. The remaining 4 showed varying degrees of minor peristaltic abnormality (due to caustic strictures in 2 and partially obstructing carcinoma of the esophagus in 2). In all patients with stricture or stenosis the intraluminal diverticulum-like structure was seen proximal to the area of narrowing. An intervening zone was filled with secretions or poorly mixed barium and retained secretions. In 1 patient with scleroderma and secondary peptic stricture due to chronic reflux esophagitis, who underwent esophagectomy with gastric pullthrough procedure, an intraluminal diverticulum-like structure was seen in the sub- 
Table 1. Clinical, radiologic and pathologic data from 12 patients with transient intraluminal diverticulum of the esophagus on barium swallow

\begin{tabular}{|c|c|c|c|c|c|c|c|c|c|c|}
\hline \multirow[t]{2}{*}{$\#$} & \multirow[t]{2}{*}{ Age } & \multirow[t]{2}{*}{ Sex } & \multirow[t]{2}{*}{ Diagnosis } & \multirow[t]{2}{*}{ Symptoms } & \multicolumn{5}{|c|}{ Radiologic findings } & \multirow[t]{2}{*}{ Endoscopy } \\
\hline & & & & & $\begin{array}{l}\text { Barium } \\
\text { swallow } \\
\text { SC/DC }\end{array}$ & $\begin{array}{l}\text { Tran- } \\
\text { sient } \\
\text { intra- } \\
\text { luminal } \\
\text { diver- } \\
\text { ticulum }\end{array}$ & $\begin{array}{l}\text { Secre- } \\
\text { tions }\end{array}$ & $\begin{array}{l}\text { Peri- } \\
\text { stalsis }\end{array}$ & $\begin{array}{l}\text { GE } \\
\text { reflux }\end{array}$ & \\
\hline 1 & 76 & $\mathrm{~F}$ & Achalasia & $\begin{array}{l}\text { Dysphagia, } \\
\text { substernal } \\
\text { burning }\end{array}$ & $\mathrm{SC}$ & + & ++ & Absent & None & Normal \\
\hline 2 & 69 & F & $\begin{array}{l}\text { Peptic stricture, } \\
\text { antireflux } \\
\text { operations, } \\
\text { esophageal } \\
\text { dilatations }\end{array}$ & $\begin{array}{l}\text { Dysphagia, } \\
\text { weight loss }\end{array}$ & $\mathrm{DC}$ & + & ++ & Poor & $\begin{array}{l}\text { Massive } \\
\text { spontaneus }\end{array}$ & $\begin{array}{l}\text { Ulceration } \\
\text { stricture, } \\
\text { biopsy specimen } \\
\text { showed, } \\
\text { Barretts } \\
\text { esophagus }\end{array}$ \\
\hline 3 & 50 & M & $\begin{array}{l}\text { Caustic } \\
\text { stricture }\end{array}$ & Dysphagia & $\mathrm{SC}$ & + & + & Poor & None & $\begin{array}{l}\text { Ulceration } \\
\text { due to } \\
\text { caustic } \\
\text { burns }\end{array}$ \\
\hline 4 & 64 & $\mathrm{~F}$ & DES & Dysphagia & $\mathrm{SC}$ & + & - & $\begin{array}{l}\text { Tertiary } \\
\text { contrac- } \\
\text { tions }\end{array}$ & None & Normal \\
\hline 5 & 30 & $\mathrm{~F}$ & $\begin{array}{l}\text { Scleroderma, } \\
3 \text { ARS }\end{array}$ & Dysphagia & $\mathrm{DC}$ & + & $\begin{array}{l}\text { Poor } \\
\text { gastric } \\
\text { emptying }\end{array}$ & Poor & None & Normal \\
\hline 6 & 21 & $\mathrm{~F}$ & $\begin{array}{l}\text { Caustic } \\
\text { stricture }\end{array}$ & Dysphagia & $\mathrm{SC}$ & + & ++ & None & None & $\begin{array}{l}\text { Gastric } \\
\text { burns, } \\
\text { stricture }\end{array}$ \\
\hline 7 & 39 & $\mathrm{~F}$ & $\begin{array}{l}\text { DES, } \\
\text { failed } \\
\text { ARS }\end{array}$ & Pain & $\mathrm{DC}$ & + & ++ & Normal & ++ & $\begin{array}{l}\text { Reflux } \\
\text { esophagitis }\end{array}$ \\
\hline 8 & 53 & M & $\begin{array}{l}\text { Caustic } \\
\text { stricture }\end{array}$ & Dysphagia & $\mathrm{SC}$ & + & ++ & $\begin{array}{l}\text { Dysmo- } \\
\text { tility }\end{array}$ & None & $\begin{array}{l}\text { Caustic } \\
\text { injury }\end{array}$ \\
\hline 9 & 74 & $\mathbf{M}$ & $\begin{array}{l}\text { Ca middle } \\
\text { esophagus }\end{array}$ & $\begin{array}{l}\text { Dysphagia, } \\
\text { weight loss }\end{array}$ & $\mathrm{DC}$ & + & ++ & Normal & None & $\begin{array}{l}\text { Ulcerating } \\
\text { carcinoma }\end{array}$ \\
\hline 10 & 34 & $\mathbf{M}$ & DES, GER & $\begin{array}{l}\text { Pain, } \\
\text { substernal } \\
\text { burning }\end{array}$ & $\mathrm{DC}$ & + & ++ & $\begin{array}{l}\text { Tertiary } \\
\text { contrac- } \\
\text { tion }\end{array}$ & ++ & $\begin{array}{l}\text { GER, other- } \\
\text { wise normal }\end{array}$ \\
\hline 11 & 66 & $\mathrm{M}$ & $\begin{array}{l}\text { Ca middle } \\
\text { esophagus }\end{array}$ & Dysphagia & $\mathrm{DC}$ & + & ++ & Normal & None & $\begin{array}{l}\text { Ulcerating } \\
\text { carcinoma }\end{array}$ \\
\hline 12 & 22 & $\mathrm{~F}$ & $\begin{array}{l}\text { DES/ achalasia, } \\
\text { Heller's } \\
\text { myotomy }\end{array}$ & $\begin{array}{l}\text { Pain, } \\
\text { dysphagia }\end{array}$ & $\mathrm{SC}$ & + & ++ & $\begin{array}{l}\text { Tertiary } \\
\text { contrac- } \\
\text { tions, } \\
\text { poor } \\
\text { peristalsis }\end{array}$ & + & Normal \\
\hline
\end{tabular}

+, Present; -, Absent; ID, Intraluminal diverticulum; ND, Not done; DES, Diffuse esophageal spasm; GER, Gastroesophageal reflux; SC, Single contrast; DC, Double contrast; LES, Lower esophageal sphincter; ARS, Antireflux surgery 
Table 1 (continued)

\begin{tabular}{ll}
\hline Results of & Treatment and \\
esophageal & follow-up \\
function & \\
tests &
\end{tabular}

Aperistalsis, increased LES pressure, normal acid clearance from esophagus

Dysmotility, GE reflux, delayed acid clearance

ND

Dysmotility, decreased LES pressure

Abnormal

ND

GER, poor acid clearance, increased LES pressure

ND

ND

GER, increased LES pressure, poor acid clearance

ND

GE reflux, decreased LES pressure, poor acid clearance
Medical therapy

followed by pneumatic balloon dilatation of GE junction

Esophagectomy and cervicalesophago gastrostomy.

Pathology: no intraluminal diverticulum

Substernal colonic interposition.

Pathology: no intraluminal diverticulum

Medical treatment

Esophagectomy with gastric pull-up. Pathology: no intraluminal diverticulum

Colonic interposition. Pathology: no intraluminal diverticulum

Colonic interposition. Pathology: no intraluminal diverticulum

Colonic interposition. Pathology: no intraluminal diverticulum

Esophagectomy and colonic interpostition. Pathology: no intraluminal diverticulum

Antireflux operation

Cervical esophagogastrostomy.

Pathology: no intraluminal diverticulum

Colonic interposition. Pathology: no intraluminal diverticulum stituted stomach. Nine patients underwent blunt esophagectomy with esophageal substitution; colon interposition was used in 6 and stomach in 3. Pathologic examination of the gross specimen revealed no evidence of intraluminal diverticulum in all 9 cases examined.

\section{Discussion}

Schreiber and David [1] reported 2 cases of intraluminal diverticulum of the esophagus. Their first patient had benign stricture of the distal esophagus and the second had recurrent gastroesophageal reflux despite having undergone antireflux surgery. These radiologic findings were not reproducible and endoscopy failed to detect any intraluminal diverticulum. Recently Cho et al. [2] described 3 cases of vanishing intraluminal diverticulum of the esophagus. Their first patient had motility disorder of the esophagus, the second patient had received radiation therapy for carcinoma of the distal esophagus. The third patient had undergone laryngoplasty and developed stenosis of the anastomosis. These findings were not reproducible on repeat barium swallows and findings on endoscopy were normal. The authors postulated that this radiographic appearance represents transient artifactual phenomenon: esophageal dysmotility with tertiary contraction may retain air in the esophagus. Improper mixing of barium mixture with secretions and/or air was perhaps a contributing factor. Cho et al. went on to suggest that awareness of this artifact improves the accuracy of interpretation of radiographs and prevents further unnecessary investigation.

Clinical and pathologic data presented in this report clearly indicate an association between disordered esophageal motility and transient flow artifacts on barium swallows. Eight of 12 patients had severe motility disorder of the esophagus. The other 4 had varying degrees of minor peristaltic abnormalities (caustic strictures in 2 and ulcerating and stenosing carcinomas of the midesophagus in 2). Of interest was 1 flow artifact closely resembling transient intraluminal diverticulum in the substituted stomach following esophagectomy for benign peptic stricture in a patient with scleroderma (case 5). Since the incidence of this phenomenon was equal in single- and double-contrast studies of the esophagus, it is postulated that techniques and barium preparations are not responsible for this finding.

The association with motility disorders of the esophagus, primary or secondary, was noteworthy in this series of cases. I have not seen this phenome- 

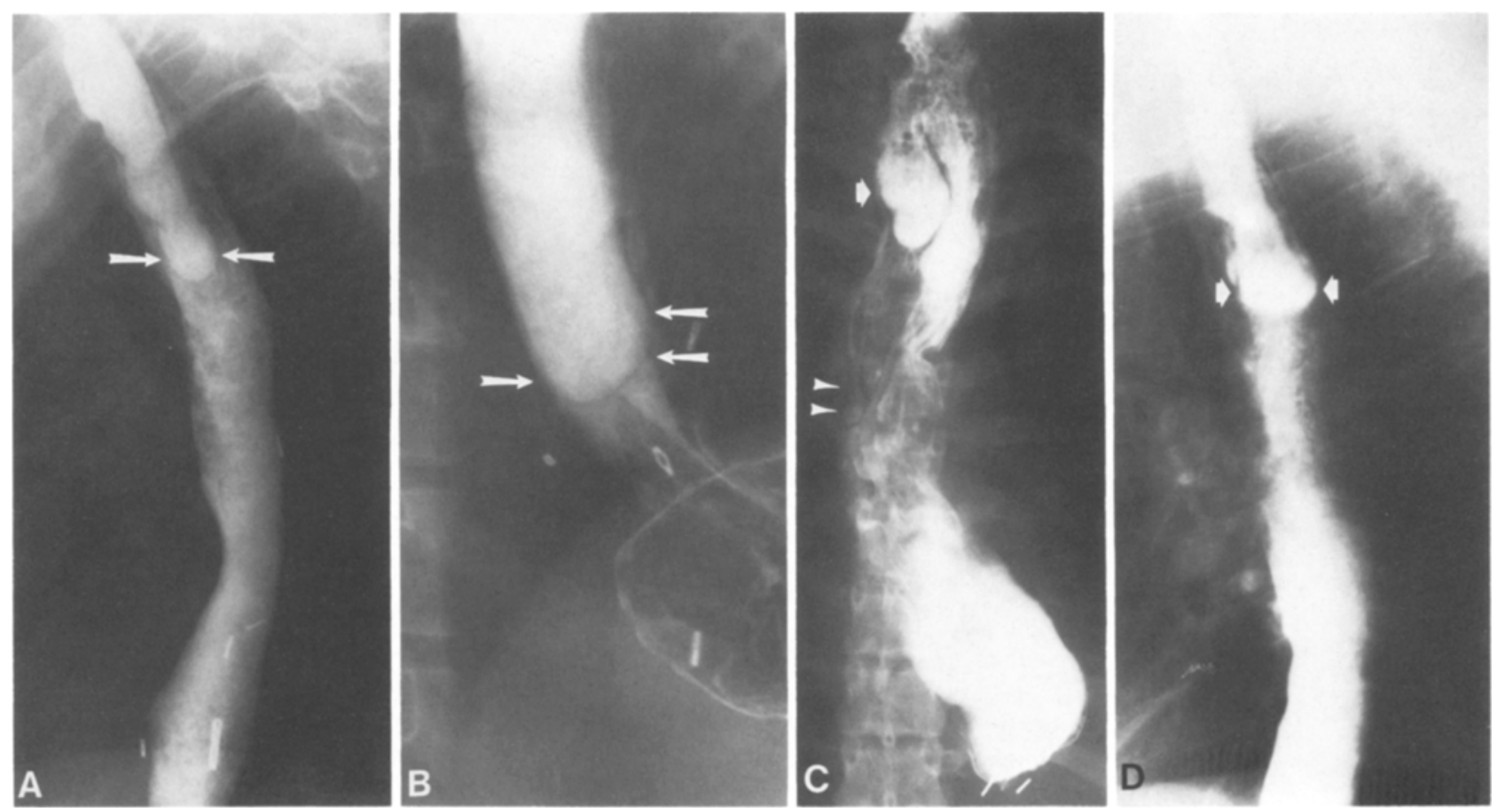

Fig. 1. A Case 12: Single-contrast esophagram shows a transient intraluminal diverticulum in the upper esophagus. A lobular ovoid collection of barium is surrounded by a thin rim of lucency (arrows). There is poor mixing of barium and retained secretions in this esophagus with neuromuscular disorder. B Case 10: A view from a single-contrast esophagram shows a transient intraluminal diverticulum in the distal esophagus (arrows) in a 34-year-old man with recurrent esophageal spasm despite previous antireflux operation. C Case 7: A view from a double-contrast esophagram shows a transient intraluminal diverticulum in the proximal esophagus. There is poor mixing of barium and retained secretions in this dilated esophagus with neuromuscular disorder. Note a comet-shaped smaller flow artifact in the midesophagus (arrowheads). D Case 1: A single-contrast esophagram shows a transient intraluminal diverticulum (arrows) in the upper esophagus in this patient with long-standing achalasia
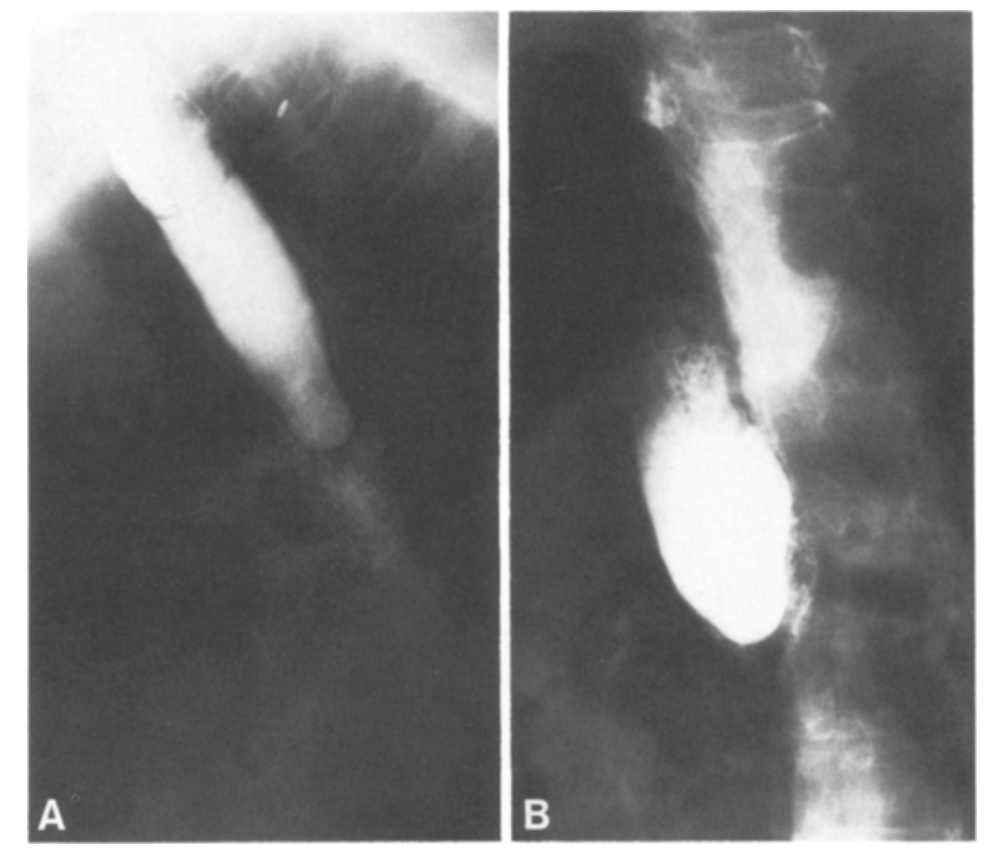

Fig. 2. Case 2 A, B Two views from a doublecontrast esophagram show a transient intraluminal diverticulum of the esophagus in this patient with chronic peptic stricture of the distal esophagus who underwent unsuccessful antireflux operation. There is poor mixing of barium and retained secretions in the dilated esophagus 


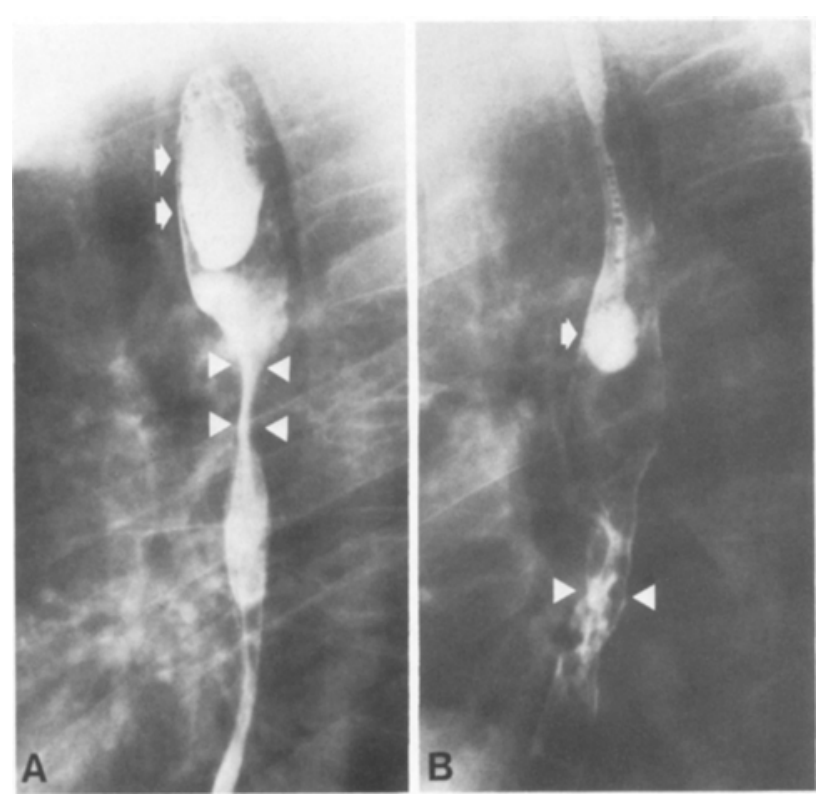

Fig. 3. A Case 9: A double-contrast view of the esophagus shows a transient intraluminal diverticulum in the slightly dilated proximal esophagus (arrows) above the stenosing carcino$\mathrm{ma}$ in the midthoracic esophagus (arrowheads). B Case 11: A double-contrast view of the esophagus shows a transient intraluminal diverticulum-like flow artifact (arrow) in the slightly dilated esophagus proximal to an ulcerating and stenosing carcinoma located in the midesophagus (arrowheads)

non in the stomach although similar evanescent findings closely simulating an intraluminal diverticulum have recently been the subject of some con- troversy [3-6]. None of the previous reports on this subject noted any pathologic proof. The data in the present series clearly prove that a transient flow phenomenon closely resembling an intraluminal diverticulum of the esophagus is not a true lesion, but an important radiographic finding suggesting underlying motility disorder of the esophagus. Whatever the mechanism of this appearance - whether improper mixing of barium mixture with viscous secretions or excessive amount of retained air - its recognition should alert the examining radiologist to an underlying primary or secondary motility disorder of the esophagus.

\section{References}

1. Schreiber $\mathrm{MH}$, Davis $\mathrm{M}$ : Intraluminal diverticulum of the esophagus. AJR 129:595-597, 1977

2. Cho SR, Henry DA, Shaw CI, Liu CI, Capel GM: Vanishing intraluminal diverticulum of the esophagus. Gastrointest $R a$ diol 7:315-317, 1982

3. Tan KM: Intraluminal diverticula of the stomach. $A J R$ 132:461-462, 1979

4. Beeckman P: Vanishing diverticula of the stomach (letter). AJR 133: 996-997, 1979

5. Tan KM: Vanishing diverticula of the stomach (letter reply), AJR 133:997, 1979

6. Shackelford GD: Barium collections in the stomach mimicking intraluminal diverticula. AJR 139:805-806, 1982

Received: September 14, 1983; accepted: November 4, 1983 